\title{
PENYULUHAN DETEKSI DINI KANKER LEHER RAHIM/KANKER SERVIKS SERTA PEMERIKSAAN IVA DI WILAYAH KERJA PUSKESMAS SEI LANGKAI BATU AJI KOTA BATAM
}

\author{
Indah Mastikana ${ }^{1}$, Eka Permata Sari ${ }^{2}$, Eva Sarnita Nasution ${ }^{3}$, \\ Nova Karlina ${ }^{4}$, Sherly Thiana Ra'ad ${ }^{5}$, Ealga Juni S.M. ${ }^{6}$, Indah Pratiwi Adhis ${ }^{7}$ \\ 1,2,3,4,5,6,7) Program Studi Kebidanan, Sekolah Tinggi Ilmu Kesehatan Awal Bros Batam \\ e-mail: indahmst2@gmail.com
}

\begin{abstract}
Abstrak
Pemeriksaan IVA merupakan pemeriksaan leher rahim (serviks) dengan cara melihat langsung (dengan mata telanjang) leher Rahim setelah meluas memulas leher rahim dengan larutan asam asetat 3-5\%. Pemeriksaan IVA merupakan pemeriksaan scrinning alternative dan papsmear karena biayanya murah, praktis, sangat mudah untuk dilaksanakan dan peralatan sederhana serta dapat dilakukan oleh tenaga kesehatan selain dokter ginekologi. Tujuan dilakukan pemeriksaan IVA untuk mengurangi morbiditas atau mortalitas dari penyakit dengan pengobatan dini terhadap kasuskasus yang ditemukan dan untuk mengetahui kelainan yang terjadi pada leher rahim. Peserta penyuluhan dan pemeriksaan ini adalah ibu yang sudah menikah, pernah melakukan hubungan seksual suami istri, sedang datang bulan/haid dan sedang hamil yang berada di Kelurahan Batu Aji Kota Batam. Kegiatan meliputi memberikan materi deteksi dini kanker mulut rahim dan Pemeriksaan IVA, serta praktik langsung kegiatan pemeriksaan IVA pada ibu. Evaluasi peningkatan pengetahuan dilakukan dengan pre dan post test. Hasil menunjukkan adanya pengetahuan yang baik sebesar $81,6 \%$, dan peserta dapat melakukan pemeriksaan IVA dengan hasil yang dapat langsung diketahui. Kesimpulan pengabdian masyarakat berupa Penyuluhan dan Pemeriksaan untuk meningkatkan pengetahuan ibu pentingnya dilakukan pemeriksaan IVA secara dini agar masyarakat dapat lebih menjaga kesehatan reproduksinya dan mencegah terjadinya penyakit kanker mulut rahim.
\end{abstract}

Kata kunci: Pengetahuan, Pemeriksaan IVA

\begin{abstract}
IVA examination is an examination of the cervix (cervix) by directly seeing (with the naked eye) the cervix after extending daub the cervix with $3-5 \%$ acetic acid solution. IVA examination is an alternative scrinning and pap smear examination because the cost is cheap, practical, very easy to carry out and simple equipment and can be done by health workers other than gynecologist. The aim of the IVA examination is to reduce the morbidity or mortality from the disease with early treatment of the cases that are found and to determine the abnormalities that occur in the cervix.

Participants in this counseling and examination are mothers who are married, have had sexual relations between husband and wife, menstruation / menstruation and are pregnant in the Batu Aji Village, Batam City. Activities include providing material for early detection of cervical cancer and IVA examination, as well as direct practice of IVA examination activities for mothers. Evaluation of increasing knowledge is done by pre and post test. The results showed that there was good knowledge of $81.6 \%$, and participants could conduct IVA examinations with results that could be immediately known. Conclusion of community service in the form of Counseling and Examination to increase maternal knowledge it is important to do an IVA examination early so that the community can better maintain their reproductive health and prevent cervical cancer.
\end{abstract}

Keywords: Knowledge, IVA examination 


\section{PENDAHULUAN}

IVA merupakan pemerikaan leher Rahim (serviks) dengan cara melihat langsung (dengan mata terlanjang) leher rahim setelah memulas leher rahim dengan larutan asam asetat 3-5\% (Samadi Priyanto, 2010). Hasil sensus penduduk pada tahun 2015, jumlah penduduk Indonesia telah mencapai sekitar 237,6 juta jiwa (Badan Kependudukan dan Keluarga Berencana Nasional, 2015). Salah satu masalah kesehatan yang menjadi perhatian dalam masyarakat adalah kesehatan reproduksi.

Kesehatan reproduksi yang cukup mendapatkan perhatian yaitu kesehatan reproduksi pada wanita. Banyak permasalahan yang menyangkut tentang kesehatan reproduksi, salah satunya adalah kanker serviks yang merupakan jenis kanker pembunuh nomor dua setelah kanker payudara pada wanita (Irianto, 2015). Menurut WHO (2010) dalam Departemen Kesehatan Republik Indonesia (2015) sekitar 490.000 wanita di seluruh dunia didiagnosa menderita kanker serviks dan 240.000 kasus kematian wanita akibat kanker serviks dan $80 \%$ kasus terjadi di negara berkembang.

Berdasarkan data dari Yayasan Peduli Kanker Serviks Indonesia tahun 2015 penderita kanker serviks di Indonesia mencapai 15.000 kasus. (Sukaca, 2015). Provinsi Kepulauan Riau, Provinsi Maluku Utara, dan Provinsi DI.Yogyakarta memiliki prevalensi kanker serviks tertinggi yaitu sebesar 1,5 \%. (KemenKes, 2015), dari data Dinas Kesehatan Kota Batam tahun 2016 tentang keikutsertan WUS pada pemeriksaaan IVA yaitu sejumlah 1.779 orang, dari hasil pemeriksaan terdapat 24 orang dengan hasil positif, 2 orang dicurigai kanker serviks 1 orang, yang krioterapi, dari jumlah sasaran 102.497 orang dengan target 3\%. Sedangkan hasil cakupan baru mencapai $1,35 \%$ berarti masih banyak wanita usia 30-60 tahun yang belum melaksanakan deteksi dini kanker serviks dengan IVA. (DinKes Kota Batam, 2016).

Kematian ibu dan bayi merupakan kegagalan kesehatan dan kegagalan sosial, oleh karena itu pola pelayanan kesehatan ibu yang relevan dengan kondisi geografis, status keluarga dan tingkat pendidikan, budaya masyarakat sangat dibutuhkan. Pola pelayanan yang tepat adalah dengan mendekatkan pelayanan kebidanan ke masyarakat. Namun tugas bidan disini bukan hanya mendekatkan pelayanan kebidanan tetapi juga menjadi penggerak atau pemimpin yang bisa menggerakkan peran serta masyarakat.

Berdasarkan masalah kesehatan pada ibu dan anak yang perlu diperhatikan oleh tenaga kesehatan, khususnya bidan komunitas. Maka diperlukan penyuluhan dan pemeriksaan IVA terhadap ibu yang yang sudah menikah dan pernah melakukan hubungan seksual,sedang datang bulan/ haid serta sedang hamil di Kelurahan Batu Aji yang bertujuan untuk memberikan pengetahuan dan melakukan pemeriksaan deteksi dini kanker serviks melalui IVA sebagai salah satu upaya menambah pengetahuan ibu dalam meningkatkan perilaku hidup sehat dalam pencegahan penyakit kanker mulut rahim. Kegiatan ini dilakukan dalam bentuk Pengabdian kepada Masyarakat (PKM) yang merupakan bagian dari kegiatan Tri Dharma Perguruan Tinggi, untuk bertujuan memberikan manfaat dan membagikan ilmu pengetahuan dan meningkatkan derajat kesehatan bagi masyarakat.

\section{METODE}

Kegiatan PKM ini dilakukan dengan metode pendidikan kesehatan pada masyarakat dalam bentuk penyuluhan dan pemeriksaan IVA. Strategi pelaksanaan dalam kegiatan ini adalah memberikan materi dengan ceramah dengan media power point menggunakan laptop dan in-focus, kemudian diakhir penyampaian materi penyuluhan, peserta diberikan kesempatan untuk bertanya sebelum dilanjutkan dengan pemeriksaan tanda-tanda vital; seperti mengukur tekanan darah, suhu, nadi dan pernapasan, kemudian dilakukan pemeriksaan IVA dengan mempersilahkan ibu membuang air kecil sebelum dilakukan pemasangan speculum paga vagina ibu, berbaring di tempat tidur dengan posisi litotomi kemudian dilakukan pemeriksaan vuva dan dilakukan tindakan vulva hygine dahulu kemudian dimasukkan speculum kedalam vagina ibu, kemudian masukkan lidi yang sudah diberi kasa serta cairan asam asetat kedalam vagina dan lakukan pengolesan pada porsio ibu dan tunggu beberapa menit kemudian lihat hasilnya apakah ada tanda-tanda kanker serviks atau tidak, lalu lakukan pendokumentasian diakhir pemeriksaan pada ibu, kemudian hasil pemeriksaan dapat langsung kami sampaikan kepada ibu. Peserta juga diberikan pre dan post test 
untuk mengukur pengetahuan dan evaluasi keberhasilan penyuluhan. Lokasi kegiatan ini dilaksanakan di Rumah kepala RW kelurahan Batu Aji Kota Batam, dengan jumlah peserta sebanyak 22 orang.

Tahap pelaksanaan dari kegiatan ini dimulai dari pengenalan fasilitator dan tujuan kegiatan, pretest, pemberian materi kanker servik yang meliputi tentang apa itu kanker serviks, tanda dan gejala, serta tujuan dilakukan pemeriksaan IVA, syarat dan jadwal pemeriksaan keuntungan serta penatalaksanaannya, tanya jawab dan post test, lalu dilakukan pemeriksaan IVA dengan pendampingan fasilitator. Evaluasi hasil dari kegiatan ini adalah dilakukan dengan memberikan post test dan melihat langsung kemampuan peserta dalam pasca pemberian penyuluhan serta peserta dapat mengetahui langsung hasil dari pemeriksaan IVA pada ibu.

\section{Dokumentasi kegiatan}

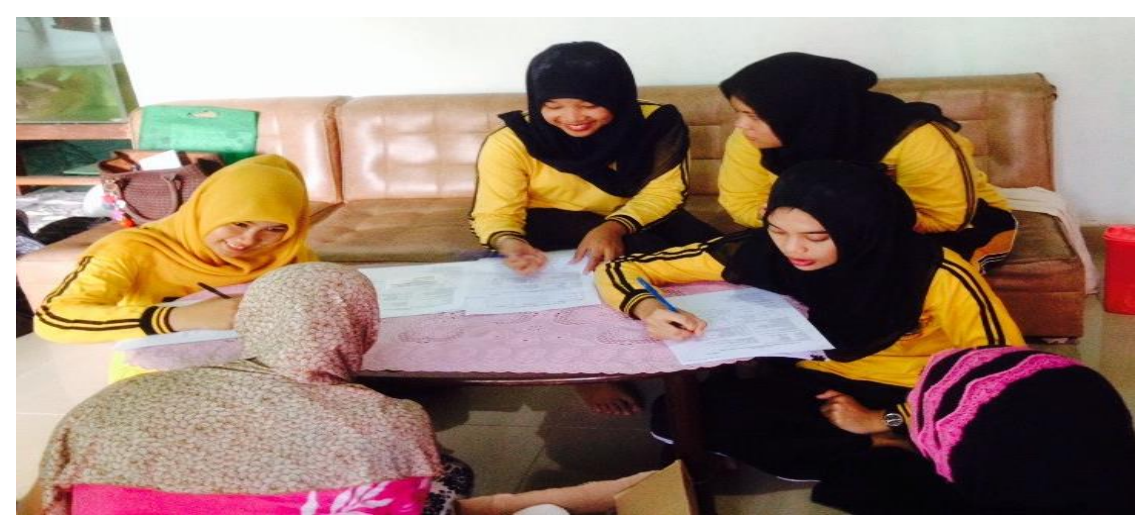

Gambar 1. Kegiatan Pendataan dan Pre Test Sebelum Dimulai Penyuluhan dan Pemeriksaan
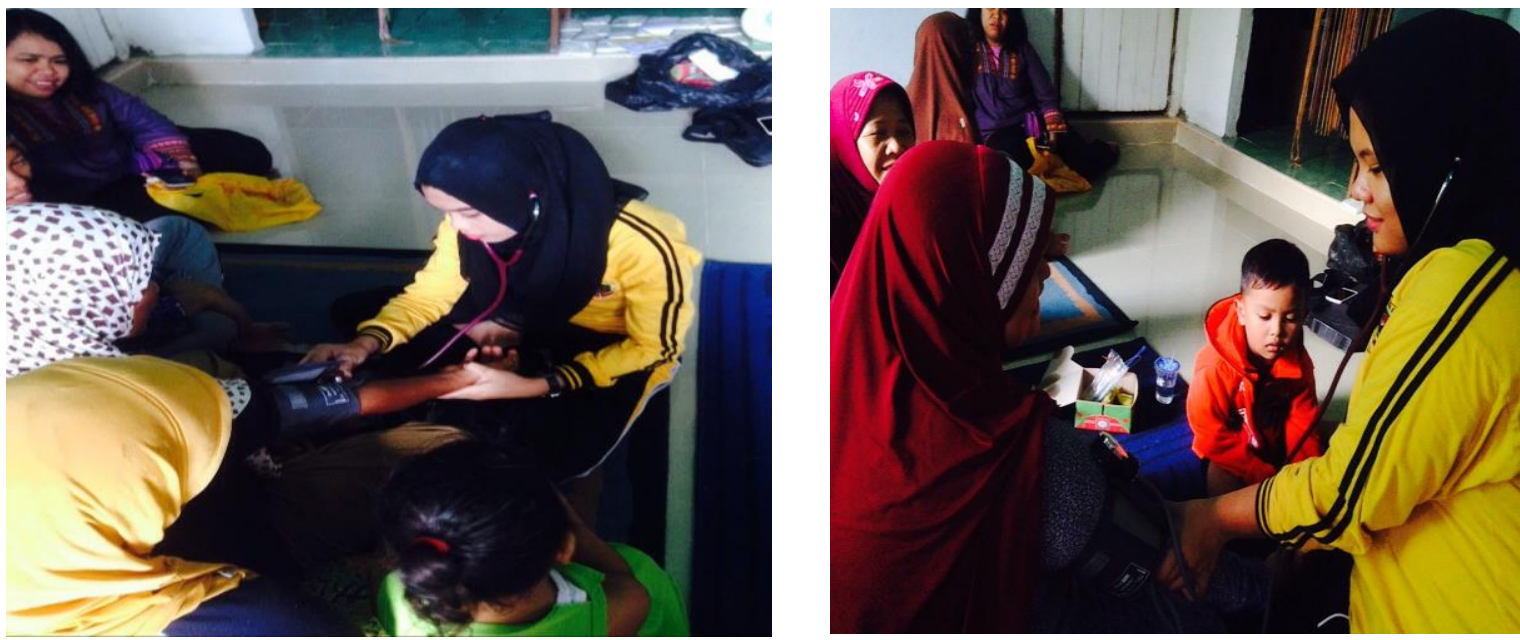

Gambar 2. Kegiatan Pemeriksaan Fisik Peserta Sebelum dilakukan pemeriksaan IVA 


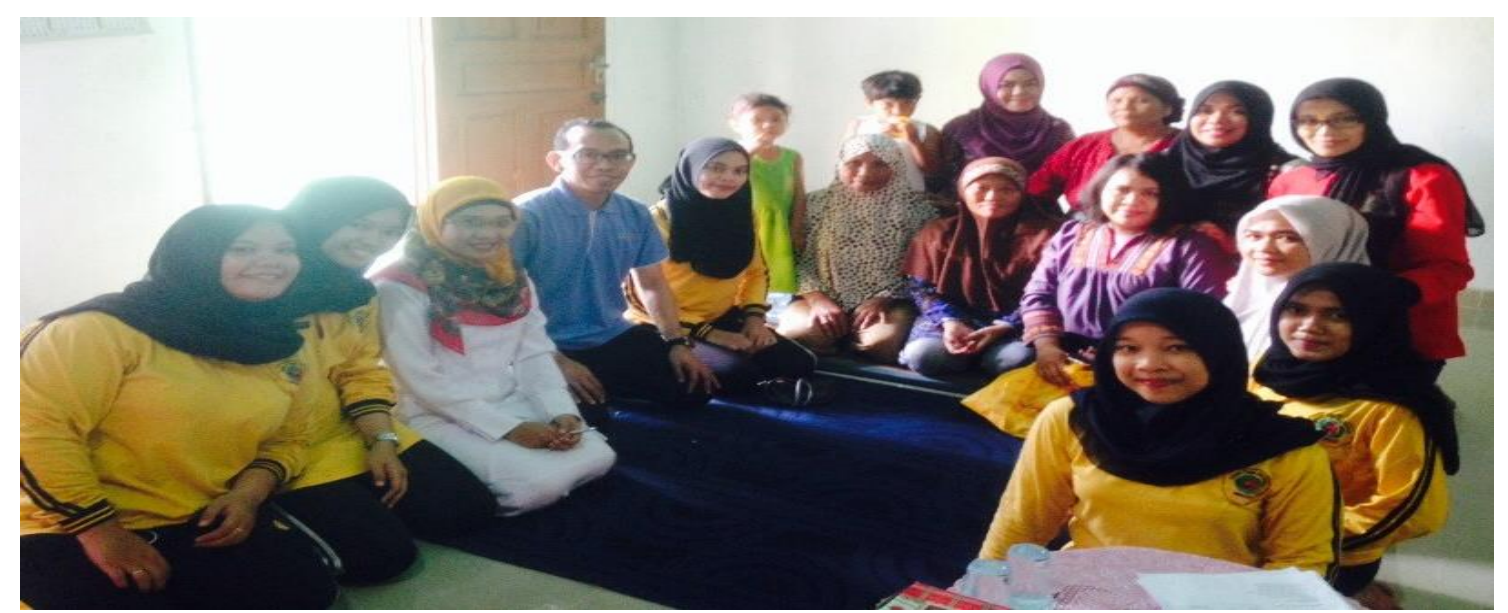

Gambar 3. Peserta Penyuluhan Kanker Serviks dan Pemeriksaan IVA
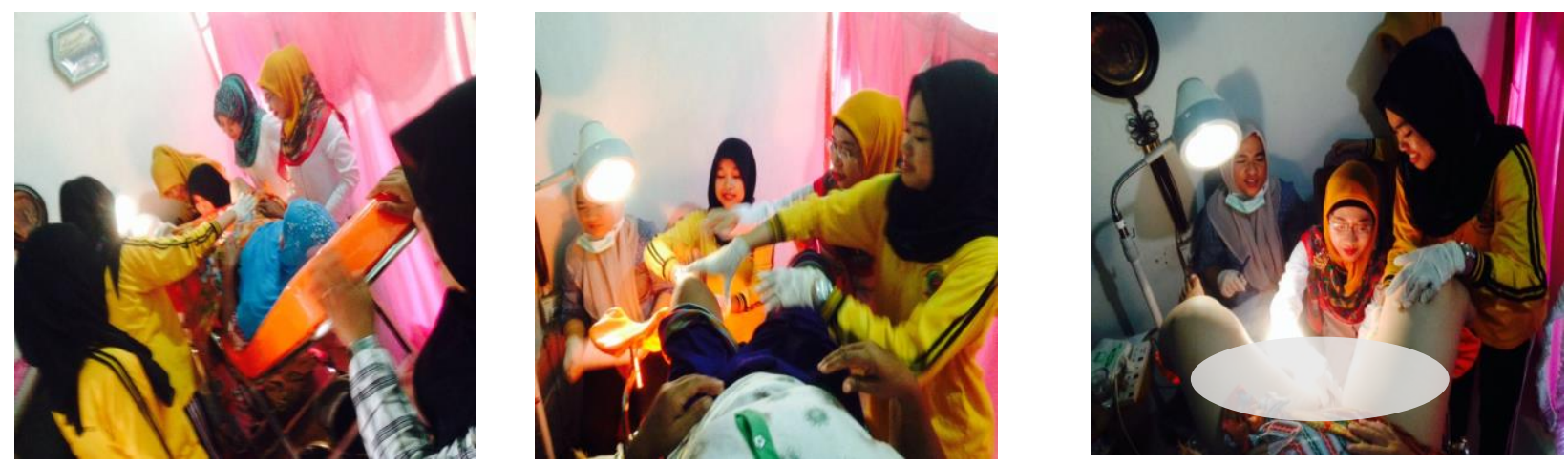

Gambar 4. Kegiatan Pemeriksaan IVA

\section{HASIL DAN PEMBAHASAN}

Hasil

1. Tahap persiapan

Melakukan rapat koordinasi dengan tim yang dilakukan pada tanggal 19 Februari 2019 dari hasil rapat disepakati untuk melakukan studi pendahuluan dengan instansi terkait yaitu: pihak Dinas Kesehatan Kota Batam, Puskesmas Sei Langkai, kader puskesmas. Setelah studi pendahuluan lalu dilakukan rapat koordinasi untuk disepakati persiapan penyuluhan dan pemeriksaan dengan persiapan materi. Kegiatan ini dibantu oleh Puskesmas dan para kader untuk menyebarkan informasi.

\section{Tahap implementasi}

Pelaksanaan kegiatan ini dilaksanakan pada Bulan 23 Maret 2019, dengan melibatkan 1 orang dosen dan enam orang mahasiswa. Kegiatan ini diikuti oleh 22 ibu. Pada saat penyampaian materi peserta mampu mengulang kembali materi yang disampaikan, peserta aktif dalam diskusi dan tanya jawab, juga antus dan mau dilakukan pemeriksaan IVA.

\section{Tahap Evaluasi}

Evaluasi hasil dari kegiatan ini adalah peserta dapat memahami materi dan mau dilakukan pemeriksaan IVA dengan baik dan lancar, dari hasil post test didapatkan peserta yang memiliki pengetahuan baik sebanyak lima belas orang dari dua puluh dua orang. Sebagian besar peserta berusia 22-42 tahun, dengan pendidikan terakhir di SMA, dengan seluruh peserta merupakan ibu rumah tangga. Peserta dan para kader antusias dalam melakukan kegiatan ini. 


\section{PEMBAHASAN}

Pada kegiatan ini peserta penyuluhan dan pemeriksaan adalah ibu-ibu yang sudah menikah, pernah melakukan hubungan seksual, sedang datang bulan/haid terakhir, dan sedang hamil yang ada di Kelurahan Batu Aji sebanyak 22 orang. Kelompok umur peserta terbanyak pada usia 22-34 tahun sebanyak 16 orang, jika dilihat dari usia peserta, dengan hasil positif kanker serviks ditemukan 1 orang dan 4 orang terlihat lesi atau lecet. Peserta yang didapatkan hasil positif dan peserta yang didapatkan hasil tampak lesi dan lecet diberikan tindakan lanjutan di Puskesmas untuk diberikan pengobatan.

Pengukuran keberhasilan kegiatan penyuluhan dan pemeriksaan IVA ini menggunakan kuesioner dan lembar pemeriksaan yang diukur sebelum dan sesudah kegiatan. Langkah- langkah dalam kegiatan ini dilakukan secara terstruktur. Diawali dengan memberikan pendidikan kesehatan dengan modul materi tentang kanker serviks, lieflet dan power point, langkah selanjutnya adalah melakukan pemeriksaan tanda-tanda vital dan pemeriksaan IVA, kemudian dengan melakukan pendampingan ibu ibu peserta dalam melakukan pemeriksaan IVA. Metode Penyuluhan adalah metode penyajian pembelajaran dengan memberitahukan pentingnya mengetahui tentang kanker serviks dan cara pemeriksaan deteksi dini, keberhasilan penyuluhan dan pemeriksaan IVA dengan menggunakan metode pembelajaran materi dapat meningkatkan pengetahuan ibu dan sikap peduli ibu dalam menjaga kesehatan reproduksinya. Menurut Melasari (2014) bahwa derajat kesehatan dipengaruhi oleh banyak factor yaitu: lingkungan, perilaku, pelayanan kesehatan dan keturunan. Factor lingkungan termasuk keadaan pemukiman atau perumahan, tempat kerja, sekolah, tempat umum, air, udara, tekhnologi, keadaan social, pendidikan dan ekonomi, sedangkan perilaku tergambar dalam kebiasaan sehari-hari seperti pola makan, kebersihan keluarga dan gaya hidup. Pelayanan kesehatan mencakup sarana kesehatan, program kesehatan dan tenaga kesehatan.

Pengetahuan kanker servik yang diberikan meliputi tentang pengertian, gejala, penyebab, diagnosis, pengobatan dan pencegahan, tujuan pemeriksaan IVA, syarat dan jadwal pemeriksaan, keuntungan dan penatalaksanaan Scrinning IVA dengan gambar dan langkah-langkah atau prosedur pemeriksaan IVA. Peningkatan pengetahuan ibu peserta dan mengikuti pemerikdaan IVA dalam kegiatan ini dapat dipengaruhi oleh beberapa faktor antara lain; penyuluhan dilakukan pada kelompok kecil yaitu berjumlah $7 / 8$ orang dalam 3 kelompok dan dengan jumlah fasilitator sebanyak dua orang, adanya pengulangan penyampaian materi dan tanya jawab, serta evaluasi dilaksanakan langsung. Meskipun peningkatan pengetahuan ibu sebagian besar adalah baik, namun masih ada beberapa ibu yang masih ragu untuk melakukan pemeriksaan IVA. Hal ini dapat disebabkan oleh pengetahuan ibu sebelumnya, dan faktor-faktor internal dan eksternal sehingga belum terlalu paham betapa pentingnya seorang wanita menjaga kesehatan reproduksinya sedini mungkin dengan memahami terjadinya penyakit kanker serviks dan rutin melakukan pemeriksaan IVA di tempat pelayanan kesehatan setempat.

\section{SIMPULAN}

Berdasarkan hasil kegiatan Pengabdian kepada Masyarakat dengan penyuluhan dan pemeriksaan IVA terhadap ibu atau pasangan usia subur di Kelurahan Batu Aji dapat disimpulkan bahwa terdapat peningkatan pengetahuan dan sikap antusiap atau peduli pada kesehatan reproduksinya dengan mengikuti pemeriksaan IVA dengan kategori baik $87 \%$.

\section{SARAN}

Saran dalam kegiatan Pengabdian kepada Masyarakat ini adalah untuk lebih peduli dan lebih berkoordinasi dengan kader-kader yang ada dengan melibatkan stekholder di wilayah setempat, dengan harapan peserta yang mengikuti kegiatan ini dapat di jadwalkan kembali dalam pemeriksaan rutin untuk melakukan pemeriksaan IVA di Puskesmas Sei Langkai, dan evaluasi dilakukan secara bertahap tidak dalam suatu waktu. 


\section{UCAPAN TERIMA KASIH}

Tim penulis mengucapkan terima kasih kepada semua pihak yang telah membantu kelancaran pelaksanaan Pengabdian Kepada Masyarakat ini di Kelurahan Batu Aji, Puskesmas Sei Langkai, dan segenap civitas akademika STIKes Awal Bros Batam dan Yayasan Bangun Bangsa.

\section{DAFTAR PUSTAKA}

Astrit safitri, 2015. Kupas Tuntas Kanker Payudara, Leher Rahim, dan Rahim. Yogyakarta : Pustaka Baru Pres

DepKes RI, 2015. Penderita Kanker Serviks di Indonesia Jakarta: Departement Kesehatan Republik Indonesia.

Kementerian Kesehatan RI, 2015. Penyakit Kanker Serviks Dan Payudara. Jakarta : Kementerian Kesehatan Indonesia.

Dinas Kesehatan Kota Batam, 2016. Klasifikasi Penduduk Kanker Serviks Kota Batam, Kota Batam : Dinas Kesehatan Kota Batam

Samadi Priyanto, 2010. Inveksi Visual AsamAsetat.Jakarta : NuhaMedika

TaufanNugroho, 2010. Jadwal Pemeriksaan Iva.Jakarta : NuhaMedika 